\title{
SOCIAL ENTREPRENEURSHIP IN AGRICULTURE, A SUSTAINABLE PRACTICE FOR SOCIAL AND ECONOMIC COHESION IN RURAL AREAS: THE CASE OF THE CZECH REPUBLIC
}

\author{
Eliška Hudcová ${ }^{1}$, Tomáš Chovanec² ${ }^{2}$ Jan Moudrý3
}

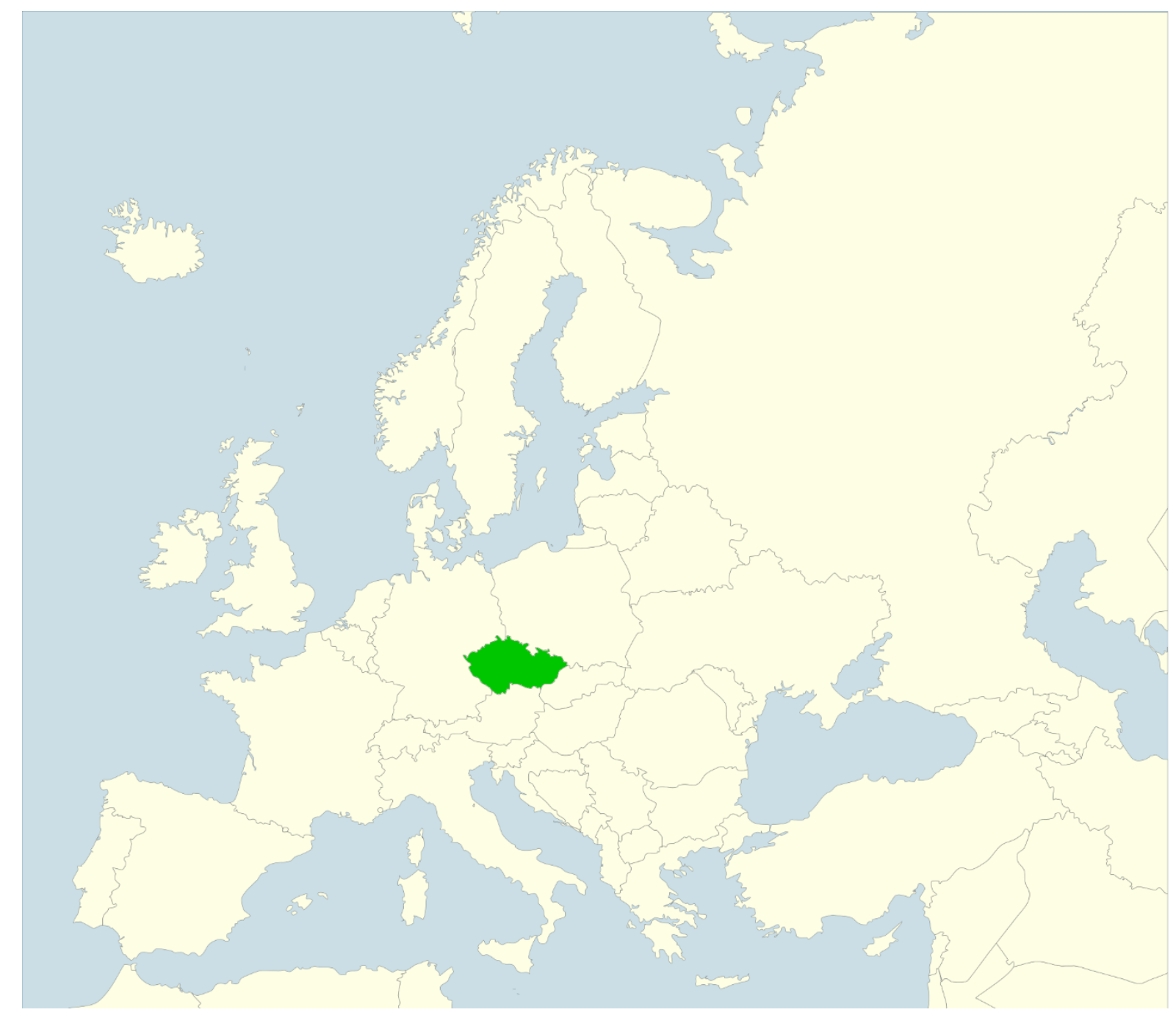

\footnotetext{
${ }^{1}$ Mgr. Bc. Eliška Hudcová (Ph.D. student), Charles University in Prague, Faculty of Humanities, Department of Civil Society Studies, U Křiže 8, 15800 Praha 5 - Jinonice; email: elahudec@seznam.cz

2 Mgr. Tomáš Chovanec (Ph.D. student), University of South Bohemia, Faculty of Agriculture, Department of Agroecosystems, Studentská 13, 37005 České Budějovice, Czech Republic; email: tomas.chovanec@cpkp.cz

3 Assoc. Prof. Ing. Jan Moudrý, Ph.D., University of South Bohemia, Faculty of Agriculture, Department of Agroecosystems, Studentská 13, 37005 České Budějovice, Czech Republic, email: jmoudry@zf.jcu.cz
} 
Abstract: This article pursues an innovative dimension of social entrepreneurship in the agricultural sector that keeps rural areas viable, so-called social farming. Social entrepreneurship appears as an essential driver in the European economy and it heads toward new opportunities mainly through its impact on social integration, economic sustainability, and fair society. Social farming and social farms can successfully respond to the challenge of social exclusion and lack of social services provision and other opportunities in rural areas through alternative therapeutic activities, sheltered working places or integrative educational activities in a farm environment. From this perspective, a social farm should correspond to the definition of a social enterprise. By introducing the basic frames of social entrepreneurship and social farming in general and in the Czech Republic, and by concentrating on fifteen Czech social farms, this paper presents an insight into this retro-innovative practice of social integration systems in the countryside. It mainly answers the question, whether social farming complies fully with social entrepreneurship stream, and it explores the role of the social farm in rural development by using semi-structured and in-depth interviews.

Keywords: rural areas, rural development, social entrepreneurship, social farming, social farm, social integration

Abstrakt: Tento článek se zaměřuje na inovativní rozměr sociálního podnikání v zemědělském sektoru, který napomáhá udržovat životaschopnost venkovských oblastí, na tzv. sociální zemědělství. Sociální podnikání se jeví jako důležitá hnací síla evropského hospodářství, a to především prostřednictvím jeho dopadu na sociální integraci, hospodářskou udržitelnost a spravedlivou společnost. Sociální zemědělství a sociální farmy mohou úspěšně reagovat na problémy sociálního vyloučení, nedostatek poskytovaných sociálních služeb a dalších přiležitostí ve venkovských oblastech prostřednictvím alternativních terapeutických aktivit, chráněných pracovních míst nebo integračních vzdělávacích aktivit ve faremním prostředí. Z této perspektivy by sociální farma měla odpovídat vymezení sociálního podniku. Tento príspěvek uvádí základní rámec sociálního podnikání a sociálního zemědělství obecně a v České republice a koncentruje se na patnáct českých sociálních farem, na nichž je představena tato inovativní praxe sociálně integračních systémů. Především odpovídá na otázku, zda sociální zemědělství splňuje indikátory sociálního podnikání, a také popisuje roli sociální farmy v rozvoji venkova za použití kvalitativních a polostrukturovaných rozhovorů.

Klíčová slova: venkovské oblasti, venkovský rozvoj, sociální podnikání, sociální zemědělství, sociální farma, sociální integrace

\section{Introduction}

The discourse on social farming, or other equivalents such as "social agriculture," "green care farming," "farming therapy" (Hassink \& van Dijk, 2006; Hine et al., 2008a), usually describes this practice as 'the use of commercial farms and agricultural landscapes as a base for promoting mental and physical health, through normal farming activity' (Hine et al., 2008b: 247). In this sense, it refers to psychological theories, which thematise therapeutic effects of the natural elements on human well-being. In this connection, the Attention Restoration Theory by Rachel and Stephen Kaplan (1989), Psycho Evolution Theory by Roger Ulrich (1983) or Theory of Biophilia by Edward O. Wilson (1984) are the most often cited (Haubenhofer, Enzenhofer, Kleber et al., 2013). On the contrary, this article emphasises an entrepreneurship approach and sees the social farm as an essential and innovative implement for keeping social, economic and environmental cohesion in rural areas using businesses actions (Hudcová, 2016a). Thus, 
the social farm can appear at first sight as a kind of social enterprise by providing public benefit activities in the farm settings.

The purpose of this article is to introduce social farming within the social entrepreneurship stream that are both being developed since the last ten years in the Czech Republic. For this reason, we proceed from describing social entrepreneurship and social enterprises that we understand as organisations or firms that successfully answer the practical and actual needs of present society in approval of entrepreneurial approaches and a particular type of governance (Pestoff, 2012). Simultaneously and following heterodox economic thought represented by Karl Polanyi (1944/2001), they do not focus on economic growth, but they present a somewhat economically sustainable perspective. Social enterprise is characterised by a continuous activity producing goods and selling services (Dohnalová, Deverová, Legnerová et al., 2015). It anticipates a high degree of autonomy toward a public sphere, a significant level of economic risk, an explicit aim to benefit the community, a limited profit distribution, and a participatory governance of social enterprise, which involves various parties affected by the activity (Defourny \& Nyssens, 2014). The paper offers background information about social entrepreneurship and more specifically focuses on Czech experience with the aim to grasp better the relationship between this practice and the social farming concept.

Next, the text continues by describing a basic framework of social farming and social farms that appear as an innovative way of resolving social problems on a local level. They connect provision of social services, and sheltered working places or integrative educational activities, in a farm environment (Di lacovo \& O'Connor, 2009). The social farming practice is, at the same time, enabled by a changing paradigm in European agriculture, including a transition from agriculturebased to a service-based economy (Hassing, Hulsing \& Grin, 2014) that goes together with the focus on the notion of multifunctional agriculture, firstly mentioned at the United Nations Conference on Environment and Development (UNCED), also known as the Rio de Janeiro Earth Summit in 1992. The idea of multifunctional agriculture (MFA) is that farming should go beyond the cheap production of food and fibre that prevails in the intensive and industrial approach to farming (Randall, 2002; Ploeg \& Roep, 2003; Wilson, 2007; Bohátová, Schwarcz et al., 2016). On the contrary, it should serve as a guardian of the historical and cultural heritage and should enhance the attraction of rural areas for tourists (Lafranchi, Giannetto, Abbate et al., 2015). Nowadays and according to Francesco Di lacovo and Deirde O'Connor (2009), the social farming concept is presented as an integral part of MFA.

In the last section, the paper presents the results of a qualitative empirical inquiry of fifteen Czech social farms. The inquiry is developed on semi-structured and in-depth interviews that were realised with owners or heads of organisations between 2015 and 2017 and are combined with other sources of evidence and compared with information presented by expert literature. It offers the basic frames of Czech social farms and tests simultaneously at what point social farming corresponds entirely with the Czech entrepreneurship approach that the paper assumes. Following this postulation, it answers the question on the state of public benefit activities provision in the farm settings on the entrepreneurial basis. In the last section, it explores the role of the social farm in rural development by using in-depth interviews.

\section{Social entrepreneurship and social enterprises}

Social entrepreneurship appears as an integral part of the third sector all over the world, and as Jacques Defourny writes (2001: 2), it presents a "new entrepreneurial spirit focused on social aims." The discourse on social entrepreneurship refers to classical theories on the third or nonprofit sector covering all types of organisations or institutions "established by people on voluntary foundations with social or community-led purposes" (Ridley-Duff \& Seanor, cit. in Taylor, 2010). The idea of a distinct third sector, apart from the traditional private sector and the public sector, began to emerge in the mid-1970s, considerably linked to new ecology movement, feminism, the crisis of the welfare state and an overwhelming neoclassical economic approach criticised, for example, by an Israeli-American sociologist Amitai Etzioni (1995). The Public good theory arises due to the inability of governmental and purely market-oriented institutions to fit well with the provision of public services (Weisbrod, 1975) and upcoming non-profit organisations (NPO) 
can fill in this gap better. Non-profit organisations appear as providing services such as the child or elder care, advocacy service and other domains where, on the one hand, the government or public bodies are not always suitable to supply, and due to an informational asymmetry of purely market-oriented firms on the other hand. This superior information can often take advantage to mislead consumers (Laville, Young \& Eynaud, 2015). The comparative advantage of non-profit organisations is related in particular to the constraint of profit distribution that serves as a key protection to consumers (Hansmann, 1980). Other third sector theories listed by Helmut Anheier (2005) refer to the public or semi-public nature and characteristic of goods and positive externalities that civil society or non-profit organisations generate for society as a whole.

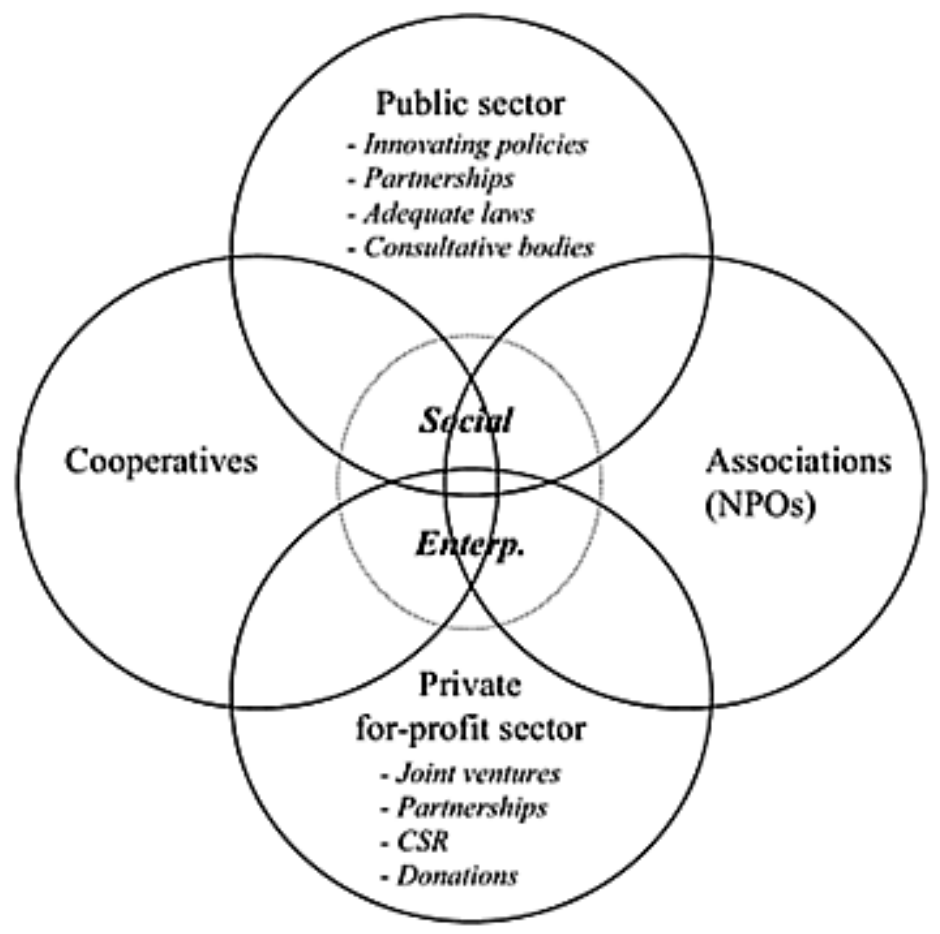

Fig 1. Social enterprises at the crossroads of public policies, for-profit companies and the third sector. Source: Hulgård (2007)

One of the primary drivers of the third sector is on the "demand side", while social enterprises often deal on the "supply side". Social entrepreneurs play the role of active creators motivated by a social or another purpose to establish new organisations, as they seek to establish a change, and in doing so, create a value. In the classic economic approach, an entrepreneur is an innovator who takes advantage of change, including the introduction of a new method of production, which opens a new market, and exploits new sources of supply or re-engineers organisation or business management process (Schumpeter, 1934). A social entrepreneur is an innovative, opportunityoriented, resourceful, value-creating change agent (Dees et al., 2001) who instead of creating a monetary value, or economic value for the firm, creates social value pursuing the specific social mission. He/she recognises and relentlessly seeks new opportunities to serve the social purpose (Gordon, 2015). Social enterprise then acts as an essential criterion for economic engagement (Young, 1981). It is a specific form of doing business in compliance with social, economic and environmental aims. Figure 1 shows the complex national economy treated by different sectors. Social enterprises appear in the middle of the private and public sector, aside from cooperative movement and non-profit associations.

While the US approach of social enterprise follows mostly Dennis Young's theory on social entrepreneur as an agent of social change, in Europe, a broader discussion on what social enterprise is, appeared in 1990, at the heart of the third sector and was closely linked with the cooperative movement. In this period, many initiatives were noticed in various other EU countries. One of them, EMES European Research Network, was established in 1996 as a result of a broad academic network of the fifteen EU countries studying "the emergence of social 
enterprise in Europe". The EMES approach gave priority to the choice of various indicators which would help identify social enterprise over a concise definition. These indicators set up by Jacques Defourny (2001) cover three dimensions: economic, social and specific type of governance.

For the economic and entrepreneurial dimension of initiatives, the criteria are:

a) a continuous activity producing goods and selling services;

b) a high degree of autonomy;

c) a significant level of economic risk;

d) a minimum amount of paid work.

The criteria for social dimensions of social enterprise present:

e) an explicit aim to benefit the community;

f) an initiative launched by a group of citizens or civil society organisations;

g) a limited profit distribution.

The last bond of criteria involves participatory governance of social enterprise that means:

h) a high degree of autonomy;

i) a decision-making power not based on capital ownership;

j) a participatory nature, which involves various parties affected by the activity. (Defourny \& Nyssens, 2014: 26-27).

As Jacques Defourny states (2014), these indicators describe an "ideal type" conditions that can hardly be attained by an organisation to deserve the name of social enterprise but they present a general understanding on how social enterprises differ from other sectors covering national economies.

\subsection{Social entrepreneurship and social enterprises in the Czech Republic}

Social entrepreneurship in Central and East European region currently comprises only an insignificant part of the national economies (Borzaga \& Galera, 2004). This evolution reflects at the same time the focus on civil society within which social entrepreneurship emerges (Skovajsa et al., 2010). It appears as a new trend in post-communist societies and develops after becoming a full member state of the European Union due to its significant support from different European investment programmes (Dohnalová, Průša et al., 2011). It was firstly in the programme period 2007-2013 when the support of social enterprises came out from the European Social Fund in the Czech Republic, and the specific features of social enterprise were established. The inspiration came from the indicators elaborated by the EMES mentioned above. These indicators, presented below in Table 1, were adopted by the TESSEA Network ${ }^{4}$ and the Ministry of Labour and Social Affairs.

\footnotetext{
4 TESSEA Network is the not-for-profit organisation for the development of the social economy that coordinates the activities for spreading the idea of social economy and social enterprise in Czech society, since 2009 http://www.tessea.cz/.
} 
Tab 1. Principles of social enterprise. Source: the TESSEA Network (2011). Arranged by the authors.

\begin{tabular}{|c|c|c|c|}
\hline $\begin{array}{l}\text { Principles of social } \\
\text { enterprise }\end{array}$ & Social benefit & Economic benefit & $\begin{array}{l}\text { Environmental and } \\
\text { local benefit }\end{array}$ \\
\hline $\begin{array}{l}\text { Characteristics and } \\
\text { features, following } \\
\text { European } \\
\text { understanding of } \\
\text { social enterprise. }\end{array}$ & $\begin{array}{l}\text { Activity is benefiting } \\
\text { society at large or } \\
\text { specific groups of } \\
\text { (disadvantaged) } \\
\text { people. }\end{array}$ & $\begin{array}{l}\text { Performing of } \\
\text { regular economic } \\
\text { activity. }\end{array}$ & $\begin{array}{l}\text { Priority is given to } \\
\text { satisfying the needs } \\
\text { of the local } \\
\text { community. }\end{array}$ \\
\hline $\begin{array}{l}\text { Social enterprises } \\
\text { have to fulfil - or to } \\
\text { evolve toward } \\
\text { a fulfilment - of } \\
\text { these criteria. }\end{array}$ & $\begin{array}{l}\text { Participation of } \\
\text { employees and } \\
\text { members in the } \\
\text { strategic planning of } \\
\text { the enterprise. } \\
\text { Any possible profits } \\
\text { are used primarily } \\
\text { for the development } \\
\text { of the social } \\
\text { enterprise and/or for } \\
\text { fulfilling community } \\
\text { goals. }\end{array}$ & $\begin{array}{l}\text { Autonomy in } \\
\text { management } \\
\text { decisions, } \\
\text { management is not } \\
\text { dependent on } \\
\text { external founders. } \\
\text { At least the minimal } \\
\text { share of the total } \\
\text { output (products or } \\
\text { services) is sold in } \\
\text { the market. } \\
\text { Ability to cope with } \\
\text { economic risk. } \\
\text { The trend toward } \\
\text { paid work. }\end{array}$ & $\begin{array}{l}\text { Favouring and using } \\
\text { local resources. } \\
\text { Satisfying, therefore, } \\
\text { the local demand. } \\
\text { Respecting } \\
\text { environmental } \\
\text { aspects of the } \\
\text { production and the } \\
\text { consumption. } \\
\text { Cooperation of the } \\
\text { social enterprise } \\
\text { with important local } \\
\text { players. } \\
\text { Innovative approach } \\
\text { and innovative } \\
\text { solutions. }\end{array}$ \\
\hline
\end{tabular}

In contrast to EMES indicators, Czech principles emphasise the environmental and local aspect of social enterprises. Also, a short overview of Czech social enterprises presents the Table 2 on main areas of social enterprises activities in the Czech Republic. The results were elaborated by the survey conducted by the TESSEA Network on social enterprises in $2015,{ }^{5}$ and they all comply with the EMES principles of social enterprise adjusted for Czech conditions.

Tab 2. Main areas of social enterprises activities. Source: Vyhodnocení, 2015.

\begin{tabular}{|l|c|c|}
\hline Main field of activities & Absolute number & Percentage \\
\hline $\begin{array}{l}\text { Gardening, maintenance of public spaces, } \\
\text { cleaning, property maintenance }\end{array}$ & 36 & $24 \%$ \\
\hline Other services & 30 & $20 \%$ \\
\hline General selling & 27 & $18 \%$ \\
\hline Restaurant services, catering and accommodation & 23 & $15 \%$ \\
\hline Food processing & 23 & $15 \%$ \\
\hline
\end{tabular}

The main purpose of Czech social enterprise is to achieve public benefit aims, and the purpose must be publicly released. Its employees or members are systematically informed about the running of the enterprise; they participate in the growth of the enterprise (participatory governance). More than $50 \%$ of income is reinvested back into the enterprise or to the reach of publicly beneficial aim. Financial surpluses are used for further development of organisation (economic criteria). This information must be publicly accessible. Social enterprise prioritises

5 The voluntary Register of social enterprises comprised at the end of 2017216 social enterprises, see also http://www.ceske-socialni-podnikani.cz/socialni-podnikani/adresar-socialnich-podniku. 
interests of the community and local demand over individual interests, it uses local resources, cooperates with local stakeholders and the management shares specific rules of cooperation in participative governance (local principle). More than $30 \%$ of employees are individuals disadvantaged in the job market due to their social or health problems. An enterprise provides them with their further placement on the job market and guarantees them psychological and social support (social benefit). These principles serve in the following part of the paper for assessing the social farm as a "pure" social enterprise.

\section{Social farming and social farms}

Social farming is usually defined as 'the use of commercial farms and agricultural landscapes as a base for promoting mental and physical health, through normal farming activity' (Hine et al., 2008b: 247). Nowadays, specific agricultural practice was always an integral part of the agricultural realm in the past as Francesco Di lacovo and Deirdre O'Connor states (2009). After the post-war era of industrialisation in agriculture and intensification of production, social farming was enabled by a changing paradigm in European agriculture, including a transition from agriculture-based to a service-based economy (Hassing, Hulsing \& Grin, 2014) and the notion of multifunctional agriculture. In this new paradigm, the farm systems influence the whole countryside, including land management, environment and ecology, water economy, species richness, historical heritage, route system and social aspects (Ploeg \& Roep, 2003). In this connection, social farming emerges as an essential activity and a base for promoting people's mental, and physical health, as well as a quality of life, for a variety of client groups (elderly people, mentally disabled people, physically handicapped people, former prisoners, youth etc.) (Hassink \& van Dijk, 2006). It is implemented in different farm contexts (intensive/extensive farming, institutional farm), and has various objectives (integrative work, training, occupational therapy, rehabilitation, prevention, education) (Bock \& Oosting, 2010; Di lacovo \& O'Connor, 2009; Sempik, Hine \& Wilcox, 2010). It is important to add, that social farming practice usually proceeds from civil and bottom-up initiatives (Chovanec, Hudcová \& Moudrý, 2015). It focuses at the same time on community development, social integration and renewed activities within social work in rural areas.

Social farming is offering its actions on social farms usually situated in the countryside. Nevertheless, the activities with everyday therapeutic use are suitable for clients living in urban care institutions too. The Table 3 below shows the different levels of care services provided on social farms or in social facilities. Some of them focus more on institutional green therapy and care; others give preference on work rehabilitation and work integration at productive farms.

Although there is a wide range of green care activities according to the Table 3 , we focus exclusively on green activities held in the farm environments. The final choice of the most favoured place for therapy, care or work integration depends on target group of clients and their preference for support. Some of them need to improve their physics, others reinforce selfconfidence and empowerment, they want to acquire practical skills, training, and new knowledge, or they want to go step-by-step back to society. The choice of the main activity according to the classification of green care and social farming from the Table 3 finally influences its coincidence with social entrepreneurship. 
Tab 3. Green care and social farming classification. Source: Di lacovo \& O'Connor (2009). Arranged by the authors.

\begin{tabular}{|c|c|c|c|}
\hline \multirow{2}{*}{\multicolumn{2}{|c|}{$\begin{array}{l}\text { Relational environment } \\
\text { Use of living species }\end{array}$}} & \multicolumn{2}{|c|}{ Level of specialization in care/agriculture activities $(-/+)$} \\
\hline & & \multirow{2}{*}{$\begin{array}{l}(-) \\
\text { Health units where } \\
\text { therapists prevail } \\
2 \\
\text { Green social units }\end{array}$} & \multirow{2}{*}{$\begin{array}{l}(+) \\
\text { Farm units, where farmers } \\
\text { prevail } \\
4 \\
\text { Inclusive farms }\end{array}$} \\
\hline $\begin{array}{l}\text { Level of } \\
\text { specialisation } \\
\text { of use of } \\
\text { living species } \\
\text { for }\end{array}$ & $\begin{array}{l}(+) \\
\text { Multifunctional } \\
\text { processes where } \\
\text { food production } \\
\text { play a key role }\end{array}$ & & \\
\hline $\begin{array}{l}\text { health/green } \\
\text { or food } \\
\text { purposes }\end{array}$ & $\begin{array}{l}(-) \\
\text { Prevalent } \\
\text { therapeutic use }\end{array}$ & $\begin{array}{l}1 \\
\text { Therapeutic green units }\end{array}$ & $\begin{array}{l}3 \\
\text { Care farms }\end{array}$ \\
\hline \multicolumn{2}{|c|}{$\begin{array}{l}\text { Specific activities: } \\
\text { AAA, animal-assisted activities } \\
\text { AAT, animal-assisted therapy } \\
\text { HT, horticultural therapy } \\
\text { FT, farming therapy }\end{array}$} & \multicolumn{2}{|c|}{$\begin{array}{l}\text { Units classification: } \\
\text { Green care: 1, 2, 3, } 4 \text { All green units/farms } \\
\text { Social Farming: 2, 3, } 4 \text { Green social units, Inclusive } \\
\text { farms, Care farms } \\
\text { Specialised Green care: } 1 \text { Therapeutic green units }\end{array}$} \\
\hline
\end{tabular}

\subsection{Social farming and social farms in the Czech Republic}

In the Czech Republic, social farming is still in its infancy (Chovanec, Hudcová \& Moudrý, 2015). The social farming practice appears as a retro-innovative concept only recently and is less widespread compared to social entrepreneurship in the Czech Republic and other Central European post-communist countries (Ujj, Moudrý, Chovanec et al., 2017). Social farming in the Czech Republic is defined on the basis of the definition stated by the European Economic and Social Committee (and says that "(s)social farming can be defined as a cluster of practices that use agricultural resources - both animal and plant - to create adequate environment for the disabled or socially disadvantaged and for the general public with the aim of providing jobs, encourage their social integration of, through education and leisure activities, contribute to their relationship to the countryside and nature. Therefore, such conditions must be created within the framework of farms or farming practices where people with particular needs can take part in daily farming routines as a way of furthering their development, making progress and improving their wellbeing." EESC, 2012: 5)

We can already find good examples of social farms in the Czech Republic, but the practice is still not as well anchored as in the Netherlands or Italy (Sempik, Hine \& Wilcox, 2010). As in the case of social entrepreneurship, it is possible to discern three reasons for its development at least. (a) It often depends on willing actors from the civil society sphere and social innovators (Hudcová, 2016b). (b) Also, European structural funds play the role of the driver in the social farming development (Dohnalová, Deverová, Legnerová et al., 2015) and experience in establishing sheltered or integration working places in agriculture with the financial support of the Labour Office within the Czech employment policy. (c) Most of the stakeholders in Czech social farming have learnt about it from international projects (Ujj, Moudrý, Chovanec et al., 2017), drawing on foreign experiences and lessons learned. This agenda that gained particular prominence as a new opportunity for rural development comes under the Ministry of Agriculture of the Czech Republic. The assumption is that farmers should be willing to accept these multiple responsibilities: to diversify the agricultural economy and to adopt more socially responsible modes of production, marketing and services. It means that it includes all farming practices that aim at integrating disadvantaged and marginalised people in the process of rural development (FAO, 2015).

For better orientation, see Figure 2 below where the social farming practice is divided into three pillars in the Czechia, as it was introduced in the first official document on social farming, published by the Ministry of Agriculture in 2015. 
According to Figure 2, we can observe similar structure of green care activities as is mentioned in Table 3. Some activities are closer to therapies in social facilities, while others focus on integrative employment and cost-effective agricultural production. The emphasis also reflects the nature of entrepreneurial efficiency of social farms.

Focus on employment

Focus on social services and support
Focus on educational activities

\section{- Objective: Employment}

- Creating jobs for people from different target groups in regular or sheltered work places, with both financial contributions and support (eg. wage contributions, mandatory benefits, etc.) as well as non-financial benefits (working with employment experts, identifying specific approaches, etc.).

- Objective: Care, therapeutic activities and preparation for employment - A set of activities that are implemented to prepare people for integration into a regular or sheltered labor market. This pillar also includes a set of social interventions aimed at activation, social rehabilitation etc., intended for clients whose integration in the labor market is minimal, and these services are therapeutic in nature.

Fig 2. Three pillars of social farming in the Czech Republic. Source: Chovanec, Hudcová \& Moudrý (2015), arranged by the authors.

\section{Methods}

Social farming in the Czech Republic appears only recently and due to low number of social farming subjects and their high variability, the research is built on a qualitative methodology approaches. The introductory descriptive part of the article pursues the content analysis (Beck \& Manuel, 2008; Coffey \& Atkinson, 1996) of scientific literature that explains an understanding of social entrepreneurship and social farming. It also defines the principles of social enterprises and main areas of practice of social farms in Czechia.

In the second step, we checked the findings from fifteen semi-structured and in-depth interviews with stakeholders from Czech social farms using triangulation (Yin, 2002; Schreier, 2012) against the scientific literature used in the introductory descriptive part. Fifteen key persons who were the farmers or heads of organisations were interviewed about their experience with the formation, running, and sustainability of their social farms. The social farms were chosen according to a theoretical purpose-built sample based on entrepreneurship theory by Young (1981) and Dees et al. (2001), and social enterprise principles by the TESSEA Network (2011). The additional framework used for the choice of social farms is their public benefit status, which defines organisations that contribute to public welfare through their activities and therefore have the opportunity to apply for public support and enjoy certain benefits (tax release, for example).

Social farms where the interviews with their representatives took place were registered on the Map of Social Farms. ${ }^{6}$ The social farms had a trade license for agricultural entrepreneurship according to Act no. 252/1997 Coll., on agriculture. There was no limitation in the legal form of

\footnotetext{
${ }^{6}$ http://www.socialni-zemedelstvi.cz/
} 
the farm. Social farms were situated in rural areas characterised by the OECD as areas with the density of inhabitants not exceeding $150 / \mathrm{km}^{2}$ (OECD, 2010).

\subsection{Data collection}

The interviews were collected between 2015 and 2017 and were divided into three areas: the first one concerned basic descriptive information about the size of the farm, and the scope of activities and products of the farm. Then the part about the history of the organisation, personal attitudes of the farmer, and the clients were discussed. Where possible, this information was compared to the data published on the websites of social farms. The third part of the interview contained themes such as different functions of agriculture, rural development and the perception of contemporary Czech countryside as general and open questions, or the role of their farm in the given locality. Each of the fifteen interviews lasted for 60 to 150 minutes. The interviews were recorded, and a transcript was made. Quotes used in this article are based on a slightly modified version of transcripts. Then the interviews were coded and analysed according to selected thematic areas and compared with the information presented by the scientific literature.

\section{Results}

This section compares the practice of social farms with the entrepreneurship theory and TESSEA Network social enterprise principles. It takes into account the public benefit performance of the farms and the social entrepreneur theory of Young and Dees et al. The localization of the farms can be found on the Fig. 3.

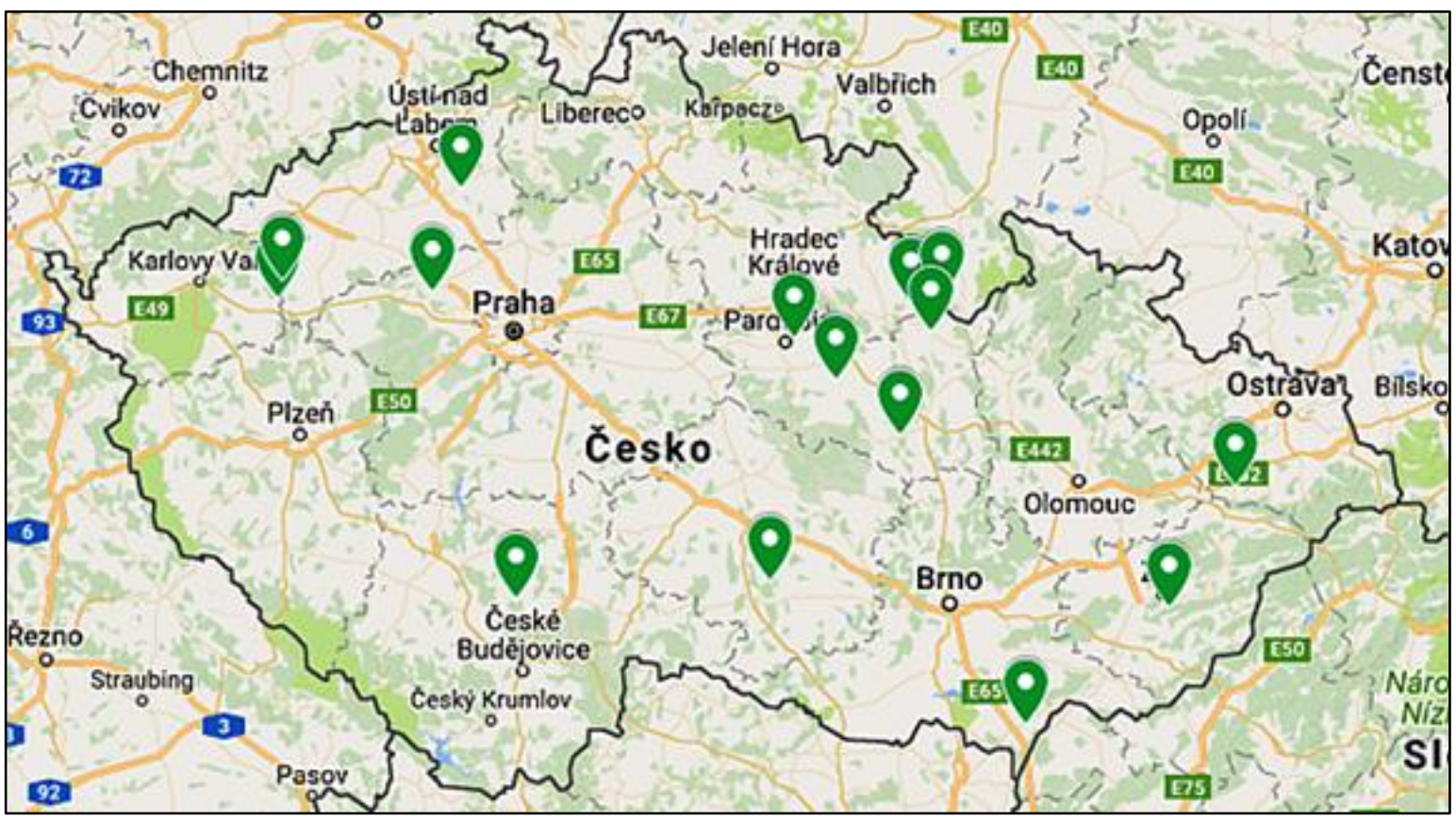

Fig 3. Localisation of the farms under study within Czechia.

\subsection{Overview of fifteen Czech social farms}

In Table 4 below, we can see the basic characteristics of the social farms. All meet at least one of the pillars stated in Figure 2 (focus on employment, focus on social services and support, focus on educational activities), some two or even all three. There are seven columns in Table 4 with a basic description of each fifteen farms: its name, farmed area, legal form, main activity, target group - for whom the activity is prepared, and information on cooperation with another legal body in the last column. We obtained this information primarily from the internet open sources and from the first part of the interviews. 
Tab 4. Characteristics of interviewed social farms. Source: the authors

\begin{tabular}{|c|c|c|c|c|c|c|}
\hline & $\begin{array}{l}\text { Name of } \\
\text { social farm }\end{array}$ & ha & Legal form & Main activity & Target group & Cooperation \\
\hline$\# 1$ & $\begin{array}{l}\text { Mgr. Vojtěch } \\
\text { Veselý, } \\
\text { Biostatek } \\
\text { (Fig. 2) }\end{array}$ & 8 & $\begin{array}{l}\text { A self- } \\
\text { employed } \\
\text { person in } \\
\text { agriculture }\end{array}$ & $\begin{array}{l}\text { Work integration, } \\
\text { education, } \\
\text { community activities }\end{array}$ & $\begin{array}{l}\text { Socially } \\
\text { excluded adults, } \\
\text { children, young } \\
\text { people, } \\
\text { volunteers, } \\
\text { public }\end{array}$ & $\begin{array}{l}\text { AREA viva, } \\
\text { z.s. } \\
\text { Association }\end{array}$ \\
\hline \#2 & $\begin{array}{l}\text { Centrum } \\
\text { slezského } \\
\text { norika }\end{array}$ & 10 & Association & $\begin{array}{l}\text { Community activities, } \\
\text { education }\end{array}$ & $\begin{array}{l}\text { Children, } \\
\text { youngsters, } \\
\text { public }\end{array}$ & $\begin{array}{l}\text { Filip Svoboda, } \\
\text { Self-employed } \\
\text { person in } \\
\text { agriculture }\end{array}$ \\
\hline \#3 & $\begin{array}{l}\text { Diana } \\
\text { Houdová }\end{array}$ & 8 & $\begin{array}{l}\text { A self- } \\
\text { employed } \\
\text { person in } \\
\text { agriculture }\end{array}$ & $\begin{array}{l}\text { Work integration } \\
\text { activities, social } \\
\text { services provision, } \\
\text { education }\end{array}$ & $\begin{array}{l}\text { Physically and } \\
\text { mentally } \\
\text { disabled adults, } \\
\text { children, public }\end{array}$ & $\begin{array}{l}\text { Apolenka, } \\
\text { z.s., } \\
\text { Association }\end{array}$ \\
\hline$\# 4$ & Dvůr Čihovice & 90 & $\begin{array}{l}\text { Limited } \\
\text { liability } \\
\text { company }\end{array}$ & $\begin{array}{l}\text { Work integration, } \\
\text { social services } \\
\text { provision }\end{array}$ & $\begin{array}{l}\text { Physically and } \\
\text { mentally } \\
\text { disabled adults, } \\
\text { public }\end{array}$ & $\begin{array}{l}\text { Pomoc Týn } \\
\text { nad Vltavou, } \\
\text { z.s., } \\
\text { Association }\end{array}$ \\
\hline$\# 5$ & Elementy & 6 & Association & $\begin{array}{l}\text { Educational } \\
\text { activities, community } \\
\text { activities }\end{array}$ & $\begin{array}{l}\text { Children, } \\
\text { youngsters, } \\
\text { public }\end{array}$ & $\begin{array}{l}\text { Jaroslav } \\
\text { Lechnýř, Self- } \\
\text { employed } \\
\text { person in } \\
\text { agriculture }\end{array}$ \\
\hline \#6 & Farma Ledce & 2 & Association & $\begin{array}{l}\text { Work integration, } \\
\text { social services } \\
\text { provision }\end{array}$ & $\begin{array}{l}\text { Physically and } \\
\text { mentally } \\
\text { disabled adults }\end{array}$ & $\begin{array}{l}\text { Etincelle, z.s., } \\
\text { Association }\end{array}$ \\
\hline$\# 7$ & $\begin{array}{l}\text { Farma Vrchní } \\
\text { Orlice }\end{array}$ & 130 & $\begin{array}{l}\text { Limited } \\
\text { liability } \\
\text { company }\end{array}$ & $\begin{array}{l}\text { Work integration, } \\
\text { social services } \\
\text { provision, community } \\
\text { activities }\end{array}$ & $\begin{array}{l}\text { Physically and } \\
\text { mentally } \\
\text { disabled adults, } \\
\text { public }\end{array}$ & $\begin{array}{l}\text { Neratov, z.s., } \\
\text { Association }\end{array}$ \\
\hline \#8 & Chaloupky & 10 & Co-operative & $\begin{array}{l}\text { Educational } \\
\text { activities, community } \\
\text { activities }\end{array}$ & $\begin{array}{l}\text { Children, } \\
\text { youngsters, } \\
\text { public }\end{array}$ & $\begin{array}{l}\text { Chaloupky, } \\
\text { o.p.s., Public } \\
\text { beneficiary } \\
\text { corporation }\end{array}$ \\
\hline$\# 9$ & $\begin{array}{l}\text { Koňský } \\
\text { dvorec } \\
\text { Chmelištná }\end{array}$ & 4 & Association & $\begin{array}{l}\text { Educational } \\
\text { activities, community } \\
\text { activities }\end{array}$ & $\begin{array}{l}\text { Youngsters, } \\
\text { inmates, public }\end{array}$ & $\begin{array}{l}\text { Václav } \\
\text { Staněk, Self- } \\
\text { employed } \\
\text { person in } \\
\text { agriculture }\end{array}$ \\
\hline$\# 10$ & $\begin{array}{l}\text { Květná } \\
\text { zahrada }\end{array}$ & 11 & Institute & $\begin{array}{l}\text { Work integration, } \\
\text { social services } \\
\text { provision, education }\end{array}$ & $\begin{array}{l}\text { Children, } \\
\text { youngsters, } \\
\text { public }\end{array}$ & \\
\hline$\# 11$ & RTK Grunt & 2 & Association & $\begin{array}{l}\text { Therapeutic and } \\
\text { resocialization } \\
\text { activities }\end{array}$ & Ex-addicts & \\
\hline$\# 12$ & Selvem & 2 & $\begin{array}{l}\text { Limited } \\
\text { liability } \\
\text { company }\end{array}$ & $\begin{array}{l}\text { Community activities, } \\
\text { education }\end{array}$ & $\begin{array}{l}\text { Community } \\
\text { activities, } \\
\text { education }\end{array}$ & \\
\hline$\# 13$ & $\begin{array}{l}\text { Statek u } \\
\text { Dubu (Fig. 3) }\end{array}$ & 30 & $\begin{array}{l}\text { Public } \\
\text { beneficiary } \\
\text { corporation }\end{array}$ & $\begin{array}{l}\text { Work integration, } \\
\text { social services } \\
\text { provision, education }\end{array}$ & $\begin{array}{l}\text { Physically and } \\
\text { mentally } \\
\text { disabled adults, } \\
\text { children, public }\end{array}$ & $\begin{array}{l}\text { Št'astný } \\
\text { domov } \\
\text { Líšnice, o.p.s., } \\
\text { Public } \\
\text { beneficiary } \\
\text { corporation }\end{array}$ \\
\hline
\end{tabular}




\begin{tabular}{|l|l|l|l|l|l|l|}
\hline & $\begin{array}{l}\text { Name of } \\
\text { social farm }\end{array}$ & ha & Legal form & Main activity & Target group & Cooperation \\
\hline \#14 & $\begin{array}{l}\text { Svobodný } \\
\text { statek na } \\
\text { soutoku }\end{array}$ & 11 & $\begin{array}{l}\text { Public } \\
\text { beneficiary } \\
\text { corporation }\end{array}$ & $\begin{array}{l}\text { Work integration, } \\
\text { social services } \\
\text { provision }\end{array}$ & $\begin{array}{l}\text { Physically and } \\
\text { mentally } \\
\text { disabled adults, } \\
\text { public, volunteer }\end{array}$ & $\begin{array}{l}\text { Camphill } \\
\text { České } \\
\text { Kopisty, z.s., } \\
\text { Association }\end{array}$ \\
\hline \#15 & $\begin{array}{l}\text { Venkovská } \\
\text { škola } \\
\text { Bludička }\end{array}$ & 28 & Association & $\begin{array}{l}\text { Educational } \\
\text { activities, community } \\
\text { activities }\end{array}$ & $\begin{array}{l}\text { Children, public, } \\
\text { physically } \\
\text { disabled people }\end{array}$ & $\begin{array}{l}\text { Radovan } \\
\text { Žitník, } \\
\text { A self- } \\
\text { employed } \\
\text { person in } \\
\text { agriculture }\end{array}$ \\
\hline
\end{tabular}

The seventh column complicates, in some cases, the simple designation of a social farm. Very often, to satisfy its mission, organisational activity is shared by two entities, and each of them is in charge of different tasks. In the usual model, there is an independent entrepreneur (selfemployed person or another legal person that can obtain financial profit) who is responsible for farm management or is an integration employer, and a non-profit organisation providing counselling, assistance to disadvantaged people, social services, or other soft, educational activities.

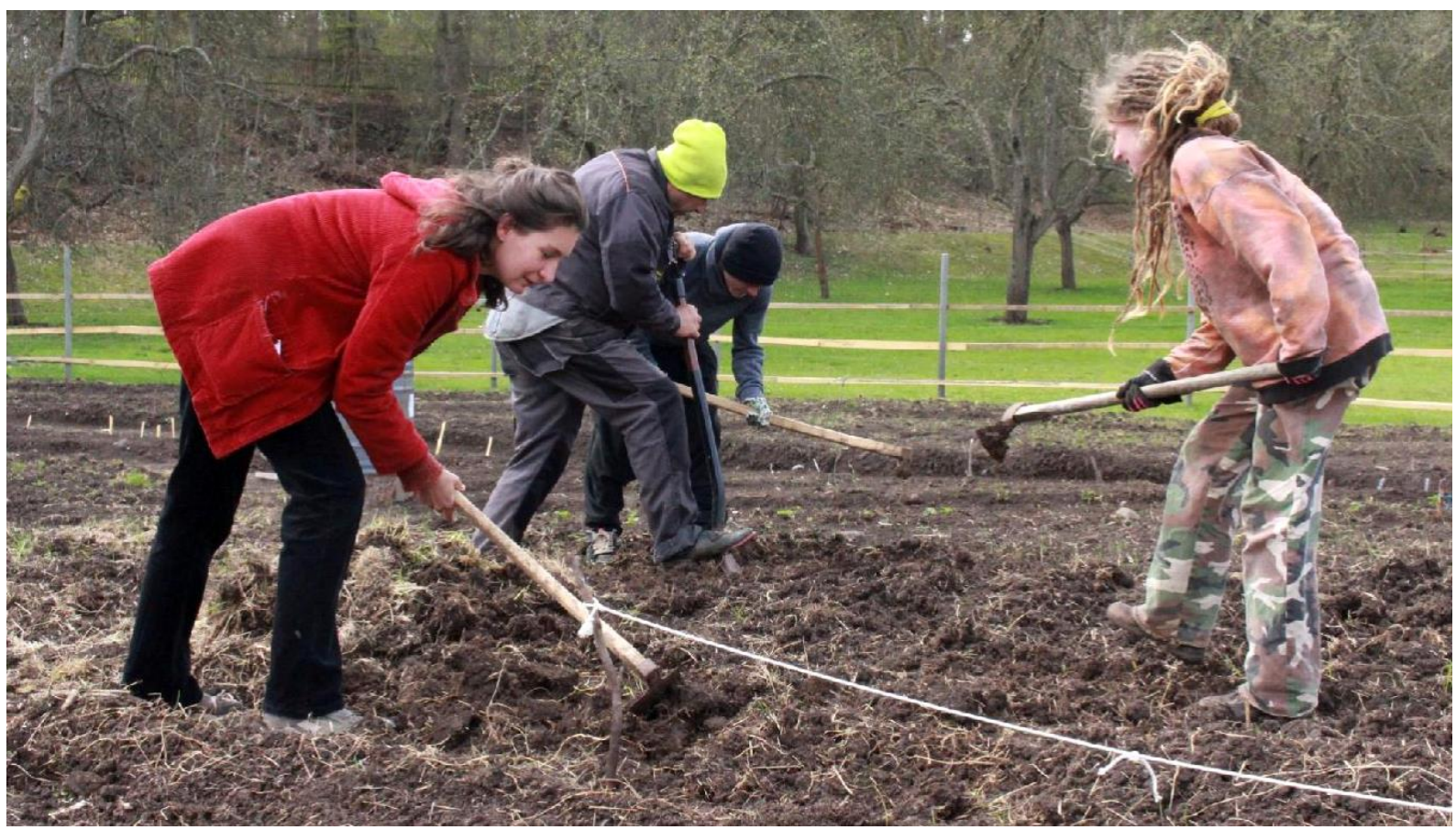

Fig 4. Biostatek Vojtěch Veselý farm. Photo: E. Hudcová

\subsection{Comparison of social entrepreneurship and social farming}

For a reason mentioned just above, we cannot simply compare the list of social farms from Table 4 with registered social enterprises, because we often deal with two organisations. If we do so, however, to find out whether a social farm is also registered in a voluntary Register of social enterprises, ${ }^{7}$ we realise that three of them are registered $(\# 1, \# 7, \# 14)$, and in other three cases $\left(\# 4, \# 6, \# 7^{8}\right)$, we find organizations closely cooperating with social farms on the list. However, in

\footnotetext{
7 http://www.ceske-socialni-

podnikani.cz/index.php?option=com form2contentsearch\&task=search .display $\& \mathrm{pb}=1 \&$ moduleid $=113 \&$ searchformid $=$ 3\&results=52\&f2cs_113_3_3=\&f2cs_113_4_3=\&f2cs_113_5_3 (cit. 2018-05-03).

8 In the case of the farm \#7, both organisations, a farm and an cooperating association, are on the list of social enterprises.
} 
these three other cases, the subjects perform different business purpose than agricultural. On the other hand, with these three social farms, we can be sure, that they meet social, economic, environmental, and local benefits. It means that more than $50 \%$ of income is reinvested back into the enterprise and financial surpluses are used for further development of the organisation. The farms are embedded in a local community and use local resources, and more than $30 \%$ of employees are individuals disadvantaged in the job market due to their social or health problems.

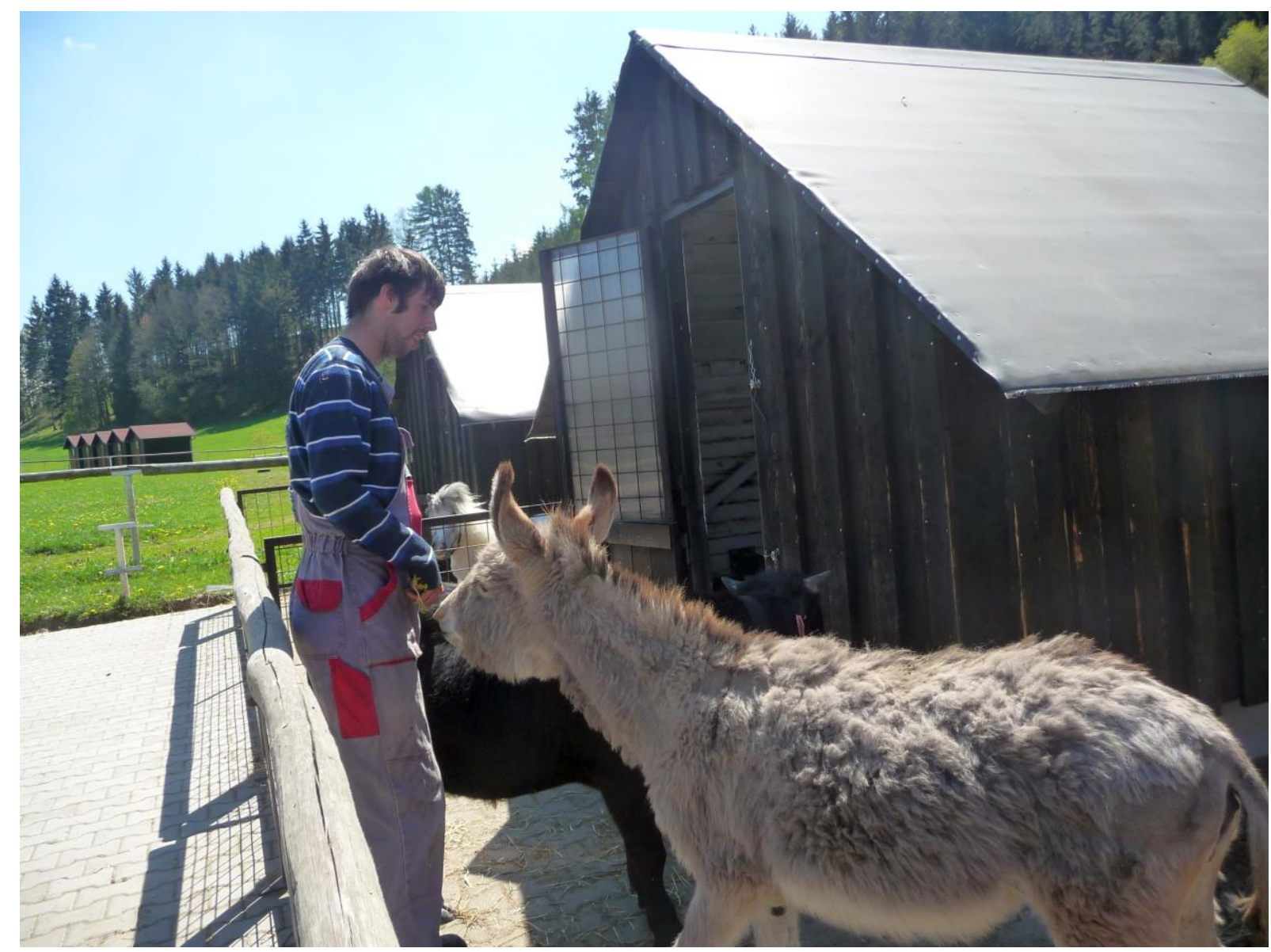

Fig 5. Statek U dubu Št’astný domov farm. Photo E. Hudcová

However, how can the other twelve social farms be assessed? If we look only at integration employment that characterises social enterprises, we can see that other farms are a place for creating sheltered jobs, even though they are not in the Register of social enterprises (\#3, \#10, \#13). In Figure 2, about the main focuses of social farms, the integration employment is one of the branches of social farming. Two others - registered social services and support, and educational activities on the farm correspond to public benefit activities meeting other than just economic goals. Registered social services provided according to the Act no108/2006 Coll, on social services in cooperation with the NPO in farm setting are proposed at farms \#4, \#6, \#7, \#8, $\# 11, \# 13, \# 14$. Educational activities for schools are regularly offered within their daily routines at farms \#1, \#2, \#3, \#5, \#8, \#15. In this area, the second and the third pillars of social farming are placed on the mission of collaborating non-profit organisations, and they fulfil the public or semipublic nature and characteristic of goods and positive externalities that they generate for society as a whole.

Also, when we focus only on comparing the TESSEA principles and with the actual status of activities of selected social farms, we find in Table 5, that in many cases these principles are not fulfilled (certified organic production meets, in this case, an environmental benefit). 
Tab 5. Social, economic, environmental and local benefits of social farms. Source: authors

\begin{tabular}{|c|c|c|c|c|c|c|c|}
\hline SF & $\begin{array}{l}\text { Limited } \\
\text { profit } \\
\text { distribution }\end{array}$ & $\begin{array}{l}\text { Participatory } \\
\text { nature of } \\
\text { governance }\end{array}$ & $\begin{array}{l}\text { Explicit aim } \\
\text { to benefit the } \\
\text { community }\end{array}$ & $\begin{array}{l}\text { Certified } \\
\text { organic } \\
\text { agriculture }\end{array}$ & $\begin{array}{l}\text { Producing } \\
\text { goods or } \\
\text { selling } \\
\text { products }\end{array}$ & $\begin{array}{l}\text { Local } \\
\text { cooperation }\end{array}$ & $\begin{array}{l}\text { Private } \\
\text { ownership }\end{array}$ \\
\hline$\# 1$ & $\checkmark$ & $x$ & $\checkmark$ & $\checkmark$ & $\checkmark$ & $\checkmark$ & $\checkmark$ \\
\hline$\# 2$ & $\checkmark$ & $\checkmark$ & $\checkmark$ & $x$ & $\checkmark$ & $\checkmark$ & $\checkmark$ \\
\hline$\# 3$ & $\checkmark$ & $x$ & $\checkmark$ & $x$ & $\checkmark$ & $\checkmark$ & $\checkmark$ \\
\hline$\# 4$ & $\checkmark$ & $x$ & $\checkmark$ & $\checkmark$ & $\checkmark$ & $\checkmark$ & $\checkmark$ \\
\hline$\# 5$ & $\checkmark$ & $\checkmark$ & $\checkmark$ & $x$ & $x$ & $\checkmark$ & $\checkmark$ \\
\hline \#6 & $\checkmark$ & $x$ & $\checkmark$ & $x$ & $\checkmark$ & $\checkmark$ & $\checkmark$ \\
\hline$\# 7$ & $\checkmark$ & $x$ & $\checkmark$ & $\checkmark$ & $\checkmark$ & $\checkmark$ & $\checkmark$ \\
\hline$\# 8$ & $\checkmark$ & $\checkmark$ & $\checkmark$ & $\checkmark$ & $\checkmark$ & $\checkmark$ & $\checkmark$ \\
\hline$\# 9$ & $\checkmark$ & $\checkmark$ & $\checkmark$ & $x$ & $\checkmark$ & $\checkmark$ & $\checkmark$ \\
\hline$\# 10$ & $\checkmark$ & $x$ & $\checkmark$ & $x$ & $\checkmark$ & $\checkmark$ & $\checkmark$ \\
\hline \#11 & $\checkmark$ & $x$ & $x$ & $x$ & $x$ & $\checkmark$ & $\checkmark$ \\
\hline$\# 12$ & $x$ & $x$ & $\checkmark$ & $\checkmark$ & $\checkmark$ & $\checkmark$ & $\checkmark$ \\
\hline \#13 & $\checkmark$ & $x$ & $\checkmark$ & $x$ & $\checkmark$ & $\checkmark$ & $\checkmark$ \\
\hline$\# 14$ & $\checkmark$ & $x$ & $\checkmark$ & $\checkmark$ & $\checkmark$ & $\checkmark$ & $\checkmark$ \\
\hline$\# 15$ & $\checkmark$ & $x$ & $\checkmark$ & $x$ & $\checkmark$ & $\checkmark$ & $\checkmark$ \\
\hline
\end{tabular}

Table 5 shows a different kind of benefits of social farms, complementary to the benefits mentioned in Table 4, and is structured under triple benefits of TESSEA Network principles. The first column is about limited profit distribution to shareholders or owners of firms that is fulfilled in all cases, except the farm \#12. The reason is that all others are either personally interconnected with a non-profit organisation, and the financial surpluses are invested into this NPO, or the farm is the NPO (\#10, \#11) and potential economic profits are according to the articles reinvested into the organisation. This situation is also affected by the multi-source financing of social farms. Revenues are a combination of financial support from their own agricultural production, land and animal subsidies, subsidies from the Labour Office to employees, European grant schemes for investment, social, and educational projects, or national and regional subsidies for social services and education. Each program has its conditions of support and financial management.

"We are dependent on subsidies, and we still have little money. We get $60 \%$ of our income from the Labour Office, and we have some income from the small sheltered shop in Žamberk." (\#13)

"Most of the money comes from AREA via soft projects that are linked to the farm. We have recently obtained the support from the Labour Office; something comes from the sale of sheep cheese and vegetables." (\#1)

The participatory nature of governance means that all employees should be involved in the decision-making process. This specification has its weaknesses in almost all cases. The point is that the farmer determines what will always be done. He is responsible for the smooth running of the organisation and, at the same time, he is an agent of social change according to Young's theory of social entrepreneur (1981) and an active creator of social change. The illustrated situation does not mean that others are not informed about the decisions or that they cannot offer some interesting suggestions. A different situation is on farms without employees (\#2, \#5, \#9) and at \#8 that is co-operative and the participative governance is prescribed by the Act no. 90/2012 Coll., on corporations.

"I make my decisions, but I also have responsibility for them, even financial ones. Let the others join, but if something goes wrong, they will also have to contribute financially." (\#10)

An explicit aim to benefit the community is often incorporated in the articles of organisations. It is not only about the services provided for disadvantaged people in the countryside. The farm is an open organism toward the wider geographically delimited area; it participates in different 
cultural events in the locality and through these actions it initiates changes toward more cohesive society. Each of the social farms is connected to other local organisations, often offering services to his or her clients and this fact supports closer local cooperation. The only farm that is enclosed in itself is \#11, a therapeutic community for ex-users with a well-defined regime, but also, in this case, it cooperates with the municipality and the clients ensure the maintenance of public spaces and municipal property.

"We cooperate with the Military History Club where we hire horses. The same with the Daycare centrum Archa whose clients come to therapeutic programs. We cooperate with the municipality, with kindergarten and elementary school, Union of goat and sheep breeders, Čertovy stezky Association." (\#15)

"We are preparing programs for children from excluded localities, so we work with the Fido Lido Association from Most, but also with the Children's Home in Maštov, and Educational Institute in Pšov. Cooperation with neighbouring farmers, Biostatek for example, is important for us too. We also participated in the Street Football World campaign for socially disadvantaged children; we co-operated with the volunteering organisation Inexsda from Prague." (\#9)

The level of community benefit purposes can also be seen in local economic prosperity that social farms contribute. In this logic, social farmers sell their products in local markets and buy necessary items in the same place, and try to keep money in that area. In some cases, they borrow machines in exchange for work without a cash shift.

"Chaloupky also strives to produce quality, fresh dairy food for the region. The farm is also part of the community supported by agriculture and cooperates predominantly with the Brno organisations such as Lipka and Lužánka Leisure Center, which provide about a third of its sales products." (\#8)

Community-supported agriculture, as a manifestation of the urban-rural relationship, also works on farms \#1 and \#14. The expression of support for the local economy is also a farm shop with

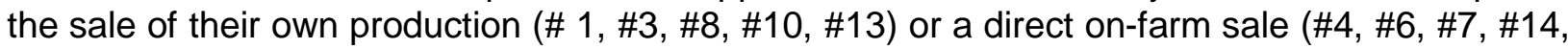
$\# 15)$. The exceptions are farms \#5 and \#11, their production cannot be officially sold, so they donate it to a limited circle of people, and produce mainly for self-supplying.

Social farming is not obligatorily connected to the certified ecological agriculture, however many social farms are organic. Additionally, as the farmers say, responsible and sustainable cultivation of the land and breeding is an integral part of their management. Often, an obstacle to organic farming is another administrative burden on the firm. Still, all social farmers are aware of the importance of the relationship to the soil and the need for its protection. Some of them move this relationship to the spiritual realm.

"The society lacks the awareness that farmers take care of the land and have a great responsibility. A farmer, he is such a co-worker of God." (\#12)

"Our image of a healthy cultural landscape is a piece of land into which one puts his work, consciousness, and shaping it into beauty, by the knowledge of the patterns in which Nature itself directs and shapes itself. Such a landscape receives from man the quality of culture and humanity. That is why every person who enters it can experience its culture and be inspired. It is a landscape that has been "returned to people" who walk, work, and perhaps sing or dance." (\#14)

All social farms from this sample are in private ownership, which means that they were not established by any public body, but solely by individual people on a voluntary basis, complying fully with EMES approach (Defourny \& Nyssens, 2014) and the TESSEA Network principles. The last point from Table 5 characterises social farms as key partners in local cooperation and this cooperation with other stakeholders in the specific geographical area was mentioned in the paragraphs above. As they cover the social, agricultural, and educational sectors, and they 
work with people dependent on the help of others, these farms work together with the Labour Office, municipalities, towns, or regions, ministries, schools, other entrepreneurs, and non-profit organisations.

Other common characteristics of social farms include diversification within their economies. Which means, that social farmers do not support monocultures, on the contrary, they keep animals and grow plants, which, in majority of cases, they process on the farm. Social farms are further close to the innovations and alternatives such as the global system WWOOF (World Wide Opportunities on Organic Farms ${ }^{9}$ ), many social farms are at the same host farms in this system $(\# 1, \# 5, \# 9)$. They promote the Community Supported Agriculture (\#1, \#8, \#14), which connect rural-urban exchange. Social farmers are also promoters of a Zero Waste lifestyle, and they sell their products into so-called No-wrap shops (\#1, \#7, \#14). Social farms are often involved in international educational, volunteering, or academic projects (\#1, \#4, \#8, \#9, \#10, \#14).

\subsection{The role of the social farm in rural development}

In the last section of this part of the paper, we concentrate on the role of the social farm in rural development, and we consider this part by the third part of the semi-structured interviews with farmers. The interview was built on questions such as different functions of agriculture, the rural development and the perception of contemporary Czech countryside as general and open questions, or the role of their farm in the given locality. We did not specify the exact criteria of rural development neither in the previous text, nor in the interviews, but we can emphasise, like in the case of social enterprises, the development of local economic factor, social factor, and environmental factor. In doing this, we realise that many results were already listed.

In the interviews, the farmers do not mention the amount of allocated financial investment. However, we can measure the localisation of the economic factor due to the existence of a farm shop and on-farm sale targeting local customers. These places of economic exchange present new trades where people disadvantaged on the open job market often find their employment. Also important are festivals and one-time events, such as a campaign "Get to know your farmer", which have an economic benefit for farmers, but also attract other small manufacturers and retailers, and hundreds of visitors.

"Get to know your farmer" was great. It has reached 900 people. The organiser ensured a bumper tractor, all-day music. Many other farmers came. For a moment, the meadow behind Valeč lived." (\#1)

Economics on social farms take the form of non-monetary exchange too, such as mutual solidarity and volunteering (previously mentioned WWOOF system, European volunteering service (\#1, \#14), or the cooperation with volunteering organisation Inexsda (\#9, \#14).

"At first, the girls were coming to ride a horse; later they got involved with their parents. We created a small community where we help each other. Families spend many hours here, and they now support our work a lot." (\#15)

The social aspect and strengthening of local cooperation can be determined by the number of stakeholders involved in the defined geographic area. The interconnectedness of rural actors promotes local social cohesion and solidarity, whether by offering employment, creating dependencies, or providing services of all sorts. This situation partly relates to ecological overlap or, in general, to functions of agriculture, which agriculture and labour bring back to their participants. Many interviewed actors compared the past times in agriculture with the present era and intensive agriculture with their small scaled and diversified social agriculture, in this connection.

"In the past, more people in the countryside met in crafts, borrowed machines. Then, agriculture received a negative touch. This is changing now; the Mayor sees that the work we do is meaningful. There is a need to involve young people more so that they can learn to re-relate to agriculture." (\#2)

\footnotetext{
${ }^{9}$ For more information see http://wwoof.net/.
} 
"The food industry wants more, the current setting, biogas stations, heavy machinery, all this eliminates nature. We want to keep the traditional economy for the children so that nature is nice and happy. Also, we see how much the clients calm down when in contact with animals and they take fewer medications. It certainly brings a sense for the society, though from an agricultural point of view it is inefficient." (\#13)

"Agricultural barons have much money from subsidies without offering back anything to the society. We are trying to open up to the public. We try to awaken the feelings for animals, to stimulate aesthetics of the landscape and nature. If we did not feel the flowers, we would not even have the positive affection for people. Without animals, the countryside would be sad." (\#15)

According to their words, the contribution of social farms to rural development lies in the protection of nature, the preservation of diversity, the preservation of the human-nature relationship. Also the transfer of the traditional farm economy to further generations and the possibility to have access to traditional agriculture play an important role in keeping rural area vivid. In this sense, social farms strive to strengthen sustainability more than its development, or sometimes they behave as if they wanted to return to old, healthy times and relationships.

\section{Discussion and conclusion}

This study aimed to describe social entrepreneurship and social farming and to present their mutual relationship. Then the purpose was to explore the basic characteristics of Czech social farms and the role of social farm in rural development. For this reason, we combined different data sources to gather insights in this specific and newly developed practice in the Czech Republic. We used mainly a content analysis of the scientific literature, open internet sources, and semi-structured and in-depth interviews with fifteen social farmers.

Although the number of social farms in the Czech Republic is not very high compared to other European countries - in Italy, for example, the number of social farms is estimated at 2000, mainly cooperatives (Lafranchi, Giannetto, Abbate \& Dimitrova, 2015; FAO, 2015); in the Netherlands, the number of social farms increased from 75 in 1998 to more than 1000 in 2009 (Hassink, Hulsink \& Grin, 2014); in the Czech Republic, the number of social farms is about three dozen (Hudcová, $2016 \mathrm{~b})$-, they bring many benefits that keep rural areas vital and economically and socially sustainable, as was presented by this contribution. In a normative way of definition, social farms promote the individual welfare and support social, economic, environmental and local benefits, and they are mission oriented. Social farms are at the same time categorised as private, autonomous organisations. They are independent to public bodies even if they often cooperate with local municipalities, Labour Offices, and other public and private entities and these findings comply fully with the social entrepreneur theory by Young (1981) and Dees et al. (2001). All farmers stress in the same vein the importance and the local markets and local human resources. Selling products and producing goods create the majority of their financial incomes even if they also ask for public subsidies within the hybrid financing that is characteristic for social enterprises (Defourny \& Nyssens, 2008) and the results of the interviews show that this is the case of social farms as well. Gained economic profits go back to the farms that promote their sustainability. Also, regarding the request of environmental and ecological sustainability, the social farms are often organic; if not, the nature-friendly farming is evident for them. Social farms differ more considerably from the social enterprises in the type of governance. The US approach to social entrepreneurship according to Young is closer to the Czech reality than the TESSEA Network and EMES European approach that shares values of democratic governance.

Although there are many common areas between social entrepreneurship and social farming, a considerable difference appears in the type of services provided. While the social enterprises are generating profits by selling goods and services and are integration employers, the social farms also offer educational and social services presented as services of general economic interest. Also, social farms usually manifest themselves as the interconnection of two bodies that provide services and create an optimal environment for clients. For this reason, it is also not easy to determine which of the subjects is or is not yet a social enterprise in the sense of TESSEA Network. Again, since the two organisations are usually run by the same person, it more closely 
coincides with the theory of a social entrepreneur who, led by mission, brings innovation and new values.

This nature of social farms activities is much more in line with the characteristics of NPOs mentioned in the paragraphs on social entrepreneurship, and they refer to the public or semipublic nature of goods and positive externalities that civil society or non-profit organisations generate for society as a whole. In these cases, social farms do not perform a business activity, but rather a provision of public benefit activities. On the other hand, there is a farm in the background, which should be economically self-sufficient, but usually, all activities are mutually interconnected and cannot be separated one from another. The social farms thus represent a specific, unique, and multifunctional setting that supports alternative kinds of social integration in the countryside entirely following a transition from agriculture-based to a servicebased rural paradigm mentioned in the introduction. As entities, social farms also participate in the sustainability of the site and the maintenance of traditional farming systems.

Rural development in the hands of social farmers lies above all in preserving the traditional nature of diversified agriculture, nature conservation and the diversity of the environment. They support the relationship between man and nature and are a reviving element of a defined geographic area. It is also the openness of social farms to their surroundings and the involvement of many different actors that fulfil a common mission and maintain cohesive rural areas.

\subsection{Recommendation for further research}

The current research should be repeated and extended to more social farming initiatives, or the social farming systems could be compared in different countries. The proposed relationships between concepts should eventually be tested by quantitative research. Future research could also extend the empirical analysis of the effects of social farms on human well-being or focus on examining the economic efficacy of social farms more precisely in a local environment. Another area of research interest could be the analysis of human capital on social farms and the role of the farmer in more extensive rural community.

\section{Acknowledgement}

This article was supported by the Programmes of Developing Academic Fields at Charles University in Prague, Internal Competition of Charles University - Progres (project no. Q20_206020/47).

Academic references

[1] Anheier, H. K. (2005). Nonprofit Organizations. Theory, Management, Policy. London, New York: Routledge.

[2] Beck, S. E. \& Manuel, K. (2008). Practical research methods for librarians and information professionals. New York: Neal-Schuman Publishers.

[3] Bock, B. B. \& Oosting, S. J. (2010). A classification of green care arrangements in Europe. In Dessein, J. \& Bock, B. B., eds., The Economics of Green Care in Agriculture (pp. 15-26). Loughborough University.

[4] Bohátová, Z., Schwarcz, P., Schwarczová, L., Bandlerová, A. \& Tl'čik, A. (2016). Multifunctionality - Interactions and Implications: The Case of the Podkylava Village (Western Slovakia). European Countryside 8(2), 147-159. DOI: 10.1515/euco-2016-0012.

[5] Coffey, A. \& Atkinson, P. (1996). Narratives and stories. In Making sense of qualitative data: Complementary research strategies (pp. 54-82). Thousand Oaks, CA: Sage Publications.

[6] Dees, J. G., Emerson, J. et al. (2001). Enterprising Nonprofits. A Toolkit for Social Entrepreneurs. New York: John Wiley and Sons. 
[7] Defourny, J. (2001). From the Third Sector to Social Enterprise. In Borzaga, C. \& Defourny, J. The Emergence of Social Enterprise (pp. 17-31). London and New York. Routledge.

[8] Defourny, J. \& Nyssens, M. (2014). The EMES Approach of Social Enterprise in a Comparative Perspective. In Defourny, J., Hulgård, L \& Pestoff, V., eds. Social Enterprise and the Third Sector: Changing European Landscapes in a Comparative Perspective (pp. 42-65). London and New York: Routledge.

[9] Defourny, J. (2014). From Third Sector to Social Enterprise. A European Research Trajectory. In Defourny, J., Hulgård, L. \& Pestoff, V., eds. Social Enterprise and the Third Sector: Changing European Landscapes in a Comparative Perspective (pp. 17-41). London and New York: Routledge.

[10] Di lacovo, F. \& O'Connor, D., eds. (2009). Supporting Policies for Social Farming in Europe. Progressing Multifunctionality in Responsive Rural Areas. ARSIA: Firenze.

[11] Dohnalová, M., Deverová, L., Legnerová, K. \& Pospišilová, T. (2015). Lidské zdroje $v$ sociálních podnicích. Praha: Wolters Kluwer, ČR, a.s.

[12] Dohnalová, M. \& Průša, L. (2011). Sociální ekonomika. Praha: Wolters Kluwer ČR, a.s.

[13] Etzioni, A. (1995). Morální dimenze ekonomiky. Praha: Victoria Publishing, a.s.

[14] Gordon, M. (2015). A Typology of Social Enterprise 'Traditions' [ICSEM Working Papers, No. 18]. University of Liege.

[15] Hansmann, H. B. (1980). The Role of Nonprofit Enterprise. The Yale Law Journal 89(5), 835901. DOI: $10.2307 / 796089$.

[16] Hassing, J., Hulsing, W. \& Grin, J. (2014). Farming with Care: the evolution of care farming in the Netherlands. NJAS - Wageningen Journal of Life Sciences. 68, 1-11. DOI: 10.1016/j.njas.2013.11.001.

[17] Hassink, J. \& van Dijk, M., eds. (2006). Farming for Health: Green Care-farming across Europe and the United States of America. Dordrecht: Springer.

[18] Haubenhofer, D., Enzenhofer, K., Kleber, S., Pflugl, S., Plitzka, E. \& Holzapfel, I. (2013). Zahradní terapie. Teorie - věda - praxe. Brno: Lipka.

[19] Hine, R., Peacock, J. \& Pretty, J. (2008b). Care Farming in the UK: Contexts, benefits and links with therapeutic communities. Therapeutic Communities. 29(3), 245-260.

[20] Hudcová, E. (2016a). Tematizace a konceptualizace sociálního zemědělství ve vztahu k sociálnímu podnikání, multifunkčnímu zemědělství a přístupům „green care" v České republice. FÓRUM sociální politiky. 10(5), 20-23.

[21] Hulgård, L. (2007). Differences between American and European Conceptions of Social Entrepreneurship. In Defourny, J., Hulgård, L. \& Pestoff, V., eds. (2014). Social Enterprise and the third sector. Changing European Landscapes in a Comparative Perspective (pp. 6684). New York, Abingdon: Routledge.

[22] Chovanec, T., Hudcová, E. \& Moudrý, J. (2015). Sociální zemědělství, představení konceptu. Praha: Ministerstvo zemědělství ČR.

[23] Kaplan, R. \& Kaplan, S. (1989). The experience of nature - a psychological perspective. Cambridge: Cambridge University Press.

[24] Lafranchi, M., Giannetto, C., Abbate, T. \& Dimitrova, V. (2015). Agriculture and the social farm: Expression of the multifunctional model of agriculture as a solution to the economic crisis in rural areas. Bulgarian Journal of Agricultural Sciences, 21(4), 711-718.

[25] Laville, J.-L., Young, D. R. \& Eynaud, P. (2015). Civil society, the Third sector and Social Enterprise. London and New York: Routledge. 
[26] Pestoff, V. (2012). Co-production and Third Sector Social Services in Europe: Some Concepts and Evidence. VOLUNTAS: International Journal of Voluntary and Nonprofit Organizations. 23(4), 1102-1118. DOI: 10.1007/s11266-012-9308-7.

[27] Ploeg, J. D. \& Roep, D. (2003). Multifunctionality and rural development: the actual situation in Europe. In Huylenbroeck, G. van \& Gilbert, D. Multifunctional Agriculture; A new paradigm for European Agriculture and Rural Development (pp. 37-53). Farnham: Ashgate.

[28] Polanyi, K. (2002). The Great Transformation: The Political and Economic Origins of Our Time, $2^{\text {nd }}$ ed. Boston: Beacon Press.

[29] Randall, A. (2002). Valuing the outputs of multifunctional agriculture. European Review of Agricultural Economics. 29(3), 289-307. DOI: 10.1093/eurrag/29.3.289.

[30] Sempik, J., Hine, R. \& Wilcox, D., eds. (2010). Green Care: A Conceptual Framework. Loughborough University.

[31] Schreier, M. (2012). Qualitative Content Analysis in Practice. Los Angeles, London, New York, New Delhi, Singapore, Washington DC: Sage.

[32] Schumpeter, J. A. (1934). The Theory of Economic Development: An Enquiry into Profits, Capital, Credit, Interests, and the Business Cycle. Cambridge, MA: Harvard University Press.

[33] Soukup, M. (2014). Terénní výzkum v sociální a kulturní antropologii. Praha: Karolinum.

[34] Taylor, R., ed. (2010). Third Sector Research. New York, Dordrecht, Heidelberg, London: Springer Sicence+Business Media.

[35] Ujj, A., ed. (2017). Social farming Best Practice Collection in Visegrad Countries. Gödöllö: Szent István Egyetem.

[36] Ulrich, E. S. (1983). Aesthetic and affective response to natural environment. In Altman, I. \& Wohlwill, J. F., eds. (1983). Behaviour and the natural environment (pp. 85-125), Boston, MA: Springer. DOI: 10.1007/978-1-4613-3539-9_4.

[37] Weisbrod, B. A. (1975). Toward a Theory of the Voluntary Non-profit Sector in a Three-sector Economy. Madison: University of Wisconsin-Madison.

[38] Wilson, E. O. (1984). Biophilia. The human bond with other species. Cambridge: Harvard University Press.

[39] Wilson, G. A. (2007). Multifunctional agriculture: A transition theory perspective. Cambridge, MA: CABI. DOI: 10.1111/j.1745-5871.2009.00580.x.

[40] Yin, R. K. (2009). Case study research: design and methods. Los Angeles: Sage.

[41] Young, D. R. (1981). Entrepreneurship and the behaviour of nonprofit organisations: Elements of a theory. In White, M., ed., Nonprofit firms in a three-sector economy. Washington, DC: Urban Institute.

\section{Other sources}

[42] Act no 108/2006 Coll., on social services.

[43] Act no. 252/1997 Coll., on agriculture.

[44] Act no. 90/2012 Coll., on corporations.

[45] Borzaga, C. \& Galera, G. (2004). Social Economy in Transition Economies: Realities and Perspectives [unpublished discussion paper presented at the First Meeting of the Scientific Group on Social Economy and Social Innovation of the OECD Centre for Local Development. Trento, Italy.

[46] EESC (2012). Social farming: green care and social and health policies: Brussels: EESC. 
[47] FAO (2015). „The Implications of Social Farming for Rural Poverty Reduction“. Technical Workshop. Final Report, Rome. Gordon, M. (2015). „A Typology of Social Enterprise 'Traditions'". ICSEM Working Papers, No. 18. Liege: The International Comparative Enterprise Models (ICSEM) Project.

[48] Hine, R., Peacock, J. \& Pretty, J. (2008a). „Care Farming in the UK: a Scoping Study“. Report for the National Care Farming Initiative. University of Essex, Colchester.

[49] Hudcová, E. (2016b). Social entrepreneurship in agriculture and its implications for new subject matters in educational curriculum. In Valenčík, R., ed., Human Capital and Investment in Education, (pp. 43-51). Praha: University of Finance and Adminitration.

[50] OECD (2010). Regional Typology. 2010. Dostupné z: http://www.oecd.org/regional/regionalpolicy/42392595.pdf.

[51] TESSEA Network (2011). Definice a principy sociálního podniku. Retrieved 2017-12-11 from: http://www.tessea.cz/tessea-o-nas/definice-a-principy-socialniho-podnikani.

[52] Vyhodnocení dotazníkového šetření sociálních podniků v ČR, 2015 (2015). Retrieved 2017-12-10 from

http://www.ceske-socialni-podnikani.cz/images/pdf/Socialni_podniky_setreni_2015.pdf. 